\title{
SSR analysis of the genomic DNA of perspective Uzbek hexaploid winter wheat varieties
}

\author{
A.T. Adylova, G.K. Norbekov, E.E. Khurshut, E.V. Nikitina @, F.N. Kushanov \\ Center of Genomics and Bioinformatics of the Academy of Sciences of the Republic of Uzbekistan, Tashkent, Uzbekistan
}

\begin{abstract}
The objective of this study was to investigate the genetic diversity of hexaploid wheat varieties of Uzbekistan breeding using simple sequence repeat (SSR) markers. These varieties are adapted to local conditions, and can be considered as the most important supplier of genetic resources for cultivation in Uzbekistan and other countries. Microsatellite markers are now most widely used and effective classes of DNA markers for genotyping, certification and classification of plant varieties. In this paper, genotyping results of 32 hexaploid wheat domestic varieties using 144 microsatellite primer pairs are presented. Microsatellite primer pairs were chosen from literature data and 36 primer pairs (from 144) gave polymorphic well-reproducible PCR-fragments. The individual SSR spectra differing in number of amplicons were obtained for each variety. A total number of 141 alleles for 36 microsatellite loci were detected. The number of alleles per locus ranged from 2 to 6 , the mean number of alleles per locus $\left(N_{a}\right)$ was 3 alleles. For the studied genotypes group the effective number of alleles ( $n e$ ) characterizing the loci by the allele frequency, varied from 1.7 to 4.8 , the mean number of alleles per locus was 2.8 . The expected heterozygosity $\left(H_{e}\right)$ ranged from 0 to 0.792 , averaging 0.626 , in studied wheat population. The amplified fragment sizes ranged from 93 to $552 \mathrm{bp}$. The polymorphic index content (PIC) ranged from 0 to 0.758 . A dendrogram was constructed using the alleles set of microsatellite loci, reflecting the phylogenetic differences of the studied hexaploid wheat varieties. It showed that Uzbekistan breeding varieties are divided into two main clusters, which may be evidence of their common origin. A genetic formula has been developed for each Uzbek wheat variety. It can be used for identification, certification of these varieties, as well as for the selection of parental pairs in the wheat breeding programs.
\end{abstract}

Key words: hexaploid winter wheat; PCR analysis; genetic diversity; microsatellite DNA loci; clusterization; barcoding.

HOW TO CITE THIS ARTICLE:

Adylova A.T., Norbekov G.K., Khurshut E.E., Nikitina E.V., Kushanov F.N. SSR analysis of the genomic DNA of perspective Uzbek hexaploid winter wheat varieties. Vavilovskii Zhurnal Genetiki i Selektsii =Vavilov Journal of Genetics and Breeding. 2018;22(6):634-639. DOI 10.18699/VJ18.404

Received 26.03.2018

Accepted for publication 08.07.2018

() AUTHORS, 2018

\section{SSR-анализ геномной ДНК перспективных сортов мягкой озимой пшеницы узбекистанской селекции}

\author{
А.Т. ААымова, Ж.К. Норбеков, Э.Э. Хуршут, \\ Е.В. Никитина $\otimes$, Ф.Н. Кушанов
}

Центр геномики и биоинформатики Академии наук Республики Узбекистан, Ташкент, Узбекистан

Целью работы было изучение генетического разнообразия сортов мягкой пшеницы узбекистанской селекции, так как они являются источником адаптированного к местным условиям обитания растительного материала и могут служить важнейшим поставщиком генетических ресурсов для селекционных работ по пшенице не только в Узбекистане, но и в других странах. В настоящее время микросателлитные маркеры (simple sequence repeats, SSR простые повторяющиеся последовательности) - одни из наиболее широко используемых и эффективных классов ДНК-маркеров для генотипирования, паспортизации и классификации сортов растений. В работе представлены результаты генотипирования 32 сортов мягкой пшеницы отечественной селекции с использованием 144 микросателлитных праймерных пар, выбранных исходя из литературных данных, 36 пар из них дали полиморфные хорошо воспроизводимые ПЦР-фрагменты. Для каждого сорта были получены индивидуальные SSR-спектры, различающиеся числом ампликонов. По 36 микросателлитным локусам выявлен 141 аллель, их число на локус $\left(N_{a}\right)$ составляло от 2 до 6 (3 в среднем). Для изученной группы генотипов эффективное число аллелей (ne), характеризующее локусы по частоте встречаемости аллелей, варьировало от 1.7 до 4.8, составляя в среднем 2.8. Величина ожидаемой гетерозиготности $\left(H_{e}\right)$ в нашей популяции пшеницы была в среднем 0.626, меняясь от 0 до 0.792. Размеры амплифицированных продуктов находились в пределах от 93 до 552 п. н. Индекс полиморфного информационного содержания (PIC) варьировал от 0 до 0.758. На основании набора аллелей микросателлитных локусов была построена дендрограмма, отражающая филогенетические различия изученных сортов мягкой пшеницы, которая показала, что сорта узбекистанской селекции разделяются на два больших кластера, это свидетельствует о возможной общности их происхождения. Для каждого сорта пшеницы Узбекистана разработана генетическая формула, которая может быть использована для идентификации, паспортизации этих сортов, а также при подборе родительских пар в селекционных программах по пшенице.

Ключевые слова: мягкая озимая пшеница; ПЦР-анализ; генетическое разнообразие; микросателлитные локусы ДНК; кластеризация; паспортизация. 
ntroduction of DNA markers into biological research opened new opportunities for studying genetic diversity of organisms (Gostimsky et al., 2005). In particular, SSR or microsatellite genome analysis of multiple plants showed that the microsatellite loci represented by multiple alleles and characterized by relatively high heterogeneity are a convenient tool for analyzing genomic DNA polymorphism.

Microsatellite locus polymorphism analysis makes it possible to obtain reproducible, informative profiles of known genome fragments and is therefore the most promising in terms of identification and certification of varieties and hybrids of cultivated plants (Sulimova, 2004).

Applicability of a marker for the stated purpose depends on the number of alleles the marker includes and their respective relative frequencies. Typically, the degree of polymorphism is quantitatively measured by two values or parameters, namely heterozygosity $(H)$, for which unbiased evaluation algorithm and variation formula are well-known (Nei, Roychoudhury, 1974; Nei, Li, 1979), and polymorphism index content $(P I C)$.

Heterozygosity is considered as an average portion of loci with two different alleles within one locus in an individual specimen. This parameter is generalized over the whole population or its part and is divided into observed $\left(H_{o}\right)$ and expected $\left(H_{e}\right)$ heterozygosity. To describe genetic diversity, expected heterozygosity is usually determined, since it is less sensitive to sample size, than the observed heterozygosity (Chesnokov, Artemyeva, 2015).

$P I C$ is determined by the marker's ability to identify population polymorphism depending on the number of detectable alleles and their frequency distributions and therefore equivalent to genetic diversity. Maximum PIC for dominant markers is 0.5 . The $P I C$ value approaches one, if locus includes multiple alleles with approximately equal occurrence rates, and equals 0 , if locus is monomorphic (Chesnokov, Artemyeva, 2015). Effective number of alleles (ne) is another parameter used to evaluate genetic diversity and is linked to heterozygosity by a simple relationship $n e=1 /\left(1-H_{e}\right)$, i.e. it is an inverse value to the percentage of homozygous loci in a specimen. It stands for the number of alleles encountered in the population with equal frequencies and ensuring the predetermined heterozygosity under random crossing (Ayala, Kiger, 1984).

The goal of the present paper is to investigate genetic structure of Uzbek hexaploid winter wheat using the aforementioned measures of genetic diversity. This problem makes for a topical research, since these varieties are a source of plant material adapted to local habitat and can be considered the most important supplier of genetic resources for wheat cultivation not only in Uzbekistan, but in other countries as well.

\section{Materials and methods}

The following 32 domestically cultivated soft wheat varieties were used in the study: Turkiston; Kelajak; Barhayot; Chillaki; Pahlavon; Farovon; Hazrati Bashir; Bardosh; Bobur; Omad; Gozgon; Matonat; Sanzar 8;
Elomon; Boysuntura; Andijon 2; Andijon 4; Dostlik; Yaksart; Muftalo; Asr; Durdona; Taraqqiyot; Kokbuloq; Bunyodkor; Hisorak; Jayhun; Uzbek; Oqmarvarid; Iftihor; Ustoz; Andijon 1; most of them included in the register of agricultural crops of Uzbekistan.

DNA isolation, amplification, electrophoresis, and visualization of amplification products were performed using standard techniques (Dellaporta et al., 1983). The study covered 51 microsatellite primer pairs (from Grain Genes Database, http://wheat.pw.usda.gov), which included 18 from WMC group (Röder et al., 1998), 12 from BARC group (Song et al., 2002), 10 from WMS group (Röder et al., 1998), 4 from CFD group (Guyomarc'h et al., 2002), 3 from GPW group (Sourdille et al., 2010), 2 from CFA group (Sourdille et al., 2010), and one pair from PSP (Devos et al., 1995) and GDM (Zhao et al., 2006) collections. Microsatellite locus alleles were identified and their sizes determined using Gel-Pro Analyzer 3.1 software. PIC value for each marker was calculated by the native script in $\mathrm{R}$ language (R Core Team, 2016), which the authors successfully used earlier (Khurshut et al., 2017). To perform statistical processing of the results and plot the diagrams required, $\mathrm{R}$ environment was used (R Core Team, 2016).

\section{Results and discussion}

DNA of 32 domestically cultivated soft wheat genotypes were probed using 144 microsatellite primer pairs selected by the authors as expectedly informative markers based on the analysis of the foreign literature, as well as earlier studies into germplasm genotyping of domestically cultivated hexaploid wheat. However in 144 microsatellite primer pairs selected, only 51 pairs were amplifiable.

As a result of SSR analysis of 32 wheat genotypes, specific and well-reproducible DNA fragments were obtained. Individual SSR spectra were identified for each variety with different amplicon numbers and sizes, as well as degree of manifestation in electrophoregrams (Fig. 1).

The following loci of small information value with $P I C<0.3$ were excluded from further research based on screening results: BARC6, BARC96, BARC139, BARC159, BARC206, CFA2149, CFA2209, GPW3032, WMC177, WMC311, WMC356, WMC367, WMC727, WMS539, WMS577. Interestingly, the CFD239 primer pair provided a single PCR product for DNA of the studied soft wheat samples, which was manifested in zero PIC value (Table 1). However it was detected in 28 out of 32 wheat varieties, and this primer pair was preserved for further research. Thus, the set of loci was narrowed down to 36 .

As a result of investigating 36 microsatellite loci, 141 alleles were identified. Their number per locus varied from 2 to 6, which produced an average of 3 alleles per locus. Maximum number of alleles, i.e. six, was identified in WMC526, CFD76, GDM33, and WMC104 loci. Five alleles were identified in eight loci, namely WMS349, PSP3000, WMC453, GPW2203, GPW2181, BARC74, WMS443, and WMS295, four alleles were identified in WMC626, WMC276, WMC445, WMC216, WMS513, WMC273, WMS291, and WMC432, and two-three alleles 


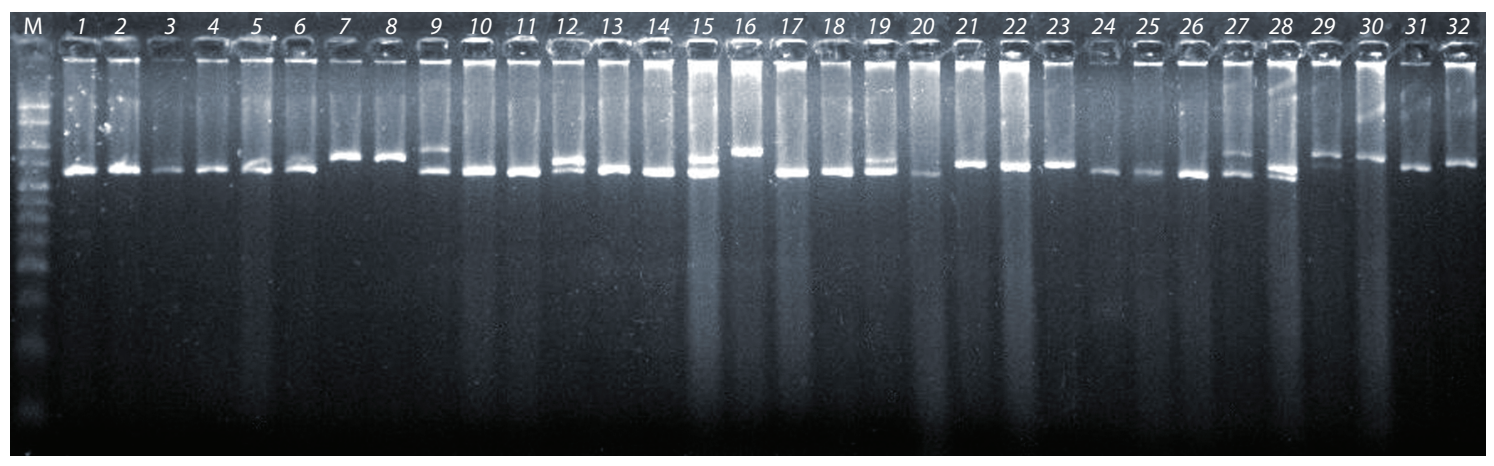

Fig. 1. Electrophoregram of the genomic DNA amplification products from Uzbek hexaploid wheat with primer PSP3000. DNA M-marker; 1-32 indicate DNA samples. (see Materials and methods).

Table 1. Characterization of microsatellite DNA loci

\begin{tabular}{|c|c|c|c|c|c|c|c|}
\hline No. & Locus & $N_{a}$ & PIC & $H_{e}$ & $\begin{array}{l}\text { Amplicon size } \\
\text { (bp) }\end{array}$ & $\begin{array}{l}\text { Effective number } \\
\text { of alleles }\end{array}$ & References \\
\hline 1 & WMS349 & 5 & 0.758 & 0.792 & $131-152$ & 4.8 & Röder et al., 1998 \\
\hline 2 & WMC526 & 6 & 0.720 & 0.762 & $169-513$ & 4.2 & Somers et al., 2004 \\
\hline 3 & PSP3000 & 5 & 0.713 & 0.750 & $233-301$ & 4.0 & Devos et al.,1995 \\
\hline 4 & CFD76 & 6 & 0.694 & 0.737 & $155-260$ & 3.8 & Guyomarc'h et al., 2002 \\
\hline 5 & WMC626 & 4 & 0.681 & 0.732 & $212-271$ & 3.7 & Somers et al., 2004 \\
\hline 6 & WMC276 & 4 & 0.677 & 0.725 & $318-349$ & 3.6 & 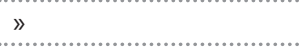 \\
\hline 7 & WMC445 & 4 & 0.666 & 0.717 & $251-283$ & 3.5 & 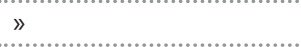 \\
\hline 8 & GDM33 & 6 & 0.663 & 0.716 & $135-266$ & 3.5 & Zhao et al., 2006 \\
\hline 9 & WMC453 & 5 & 0.661 & 0.708 & $176-230$ & 3.4 & Somers et al., 2004 \\
\hline 10 & GPW2203 & 5 & 0.661 & 0.715 & $185-332$ & 3.5 & Sourdille et al., 2004 \\
\hline 11 & GPW2181 & 5 & 0.655 & 0.710 & $146-310$ & 3.4 & 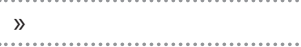 \\
\hline 12 & WMC216 & 4 & 0.639 & 0.695 & $93-146$ & 3.2 & Somers et al., 2004 \\
\hline 13 & BARC74 & 5 & 0.628 & 0.674 & $105-133$ & 3.6 & Lowe et al., 2011 \\
\hline 14 & WMC104 & 6 & 0.613 & 0.676 & $160-430$ & 3.1 & Somers et al., 2004 \\
\hline 15 & WMS513 & 4 & 0.605 & 0.668 & $127-164$ & 3.0 & Röder et al., 1998 \\
\hline 16 & WMC273 & 4 & 0.596 & 0.651 & $190-278$ & 2.8 & Somers et al., 2004 \\
\hline 17 & CFD23 & 3 & 0.585 & 0.659 & $253-283$ & 2.9 & Guyomarc'h et al., 2002 \\
\hline 18 & WMS630 & 3 & 0.581 & 0.655 & $173-203$ & 2.8 & Röder et al., 1998 \\
\hline 19 & WMS291 & 4 & 0.576 & 0.645 & $116-192$ & 2.8 & , \\
\hline 20 & WMC198 & 3 & 0.576 & 0.651 & $210-283$ & 2.8 & Somers et al., 2004 \\
\hline 21 & WMC367 & 3 & 0.572 & 0.645 & $159-194$ & 2.8 & $》$ \\
\hline 22 & WMS495 & 3 & 0.567 & 0.641 & $134-166$ & 2.7 & Röder et al., 1998 \\
\hline 23 & BARC182 & 3 & 0.565 & 0.642 & $106-134$ & 2.7 & Somers et al., 2004 \\
\hline 24 & WMS512 & 3 & 0.562 & 0.639 & $195-204$ & 2.7 & Röder et al., 1998 \\
\hline 25 & WMC166 & 3 & 0.515 & 0.586 & $353-402$ & 2.4 & Somers et al., 2004 \\
\hline 26 & CFD267 & 3 & 0.504 & 0.589 & $263-313$ & 2.4 & Guyomarc'h et al., 2002 \\
\hline 27 & WMS443 & 5 & 0.499 & 0.580 & $127-237$ & 2.3 & Röder et al., 1998 \\
\hline 28 & BARC176 & 3 & 0.489 & 0.562 & $231-296$ & 2.2 & Somers et al., 2004 \\
\hline 29 & BARC175 & 3 & 0.477 & 0.569 & $224-246$ & 2.3 & . \\
\hline 30 & WMC167 & 3 & 0.472 & 0.560 & $204-222$ & 2.2 & 》 \\
\hline 31 & WMS295 & 5 & 0.467 & 0.550 & $232-552$ & 2.2 & Röder et al., 1998 \\
\hline 32 & BARC 80 & 3 & 0.460 & 0.542 & $112-130$ & 2.1 & Somers et al., 2004 \\
\hline 33 & WMC432 & 4 & 0.456 & 0.498 & $197-257$ & 1.9 & ( \\
\hline 34 & BARC187 & 3 & 0.378 & 0.428 & $273-308$ & 1.7 & Lowe et al., 2011 \\
\hline 35 & BARC96 & 2 & 0.357 & 0.465 & $184-202$ & 1.8 & Song et al., 2002 \\
\hline 36 & CFD239 & 1 & 0.000 & 0.000 & 249 & 0.0 & Guyomarc'h et al., 2002 \\
\hline \multicolumn{2}{|c|}{ Average } & 3 & 0.564 & 0.626 & & 2.8 & \\
\hline
\end{tabular}


Table 2. Genotype formulas of hexaploid winter wheat of Uzbekistan breeding

\begin{tabular}{ll}
\hline Variety & Formula \\
\hdashline Hazrati Bashir & $\mathrm{A}_{5} \mathrm{~B}_{1} \mathrm{~B}_{2} \mathrm{~B}_{3} \mathrm{~B}_{6} \mathrm{C}_{4} \mathrm{D}_{3} \mathrm{D}_{6} \mathrm{E}_{1} \mathrm{~F}_{4} \mathrm{G}_{1} \mathrm{H}_{1} \mathrm{H}_{2} \mathrm{H}_{4} \mathrm{I}_{3} \mathrm{I}_{4} \mathrm{~J}_{1} \mathrm{~J}_{4} \mathrm{~K}_{1} \mathrm{~K}_{2} \mathrm{~K}_{4} \mathrm{~L}_{2} \mathrm{~L}_{4} \mathrm{M}_{3} \mathrm{M}_{4} \mathrm{~N}_{1} \mathrm{~N}_{2} \mathrm{O}_{3} \mathrm{P}_{2} \mathrm{P}_{3}$ \\
\hdashline Andijon 1 & $\mathrm{~A}_{1} \mathrm{~B}_{1} \mathrm{~B}_{2} \mathrm{~B}_{3} \mathrm{~B}_{6} \mathrm{C}_{3} \mathrm{D}_{2} \mathrm{D}_{5} \mathrm{E}_{3} \mathrm{~F}_{3} \mathrm{G}_{2} \mathrm{H}_{1} \mathrm{H}_{2} \mathrm{I}_{1} \mathrm{I}_{2} \mathrm{I}_{3} \mathrm{~J}_{2} \mathrm{~K}_{1} \mathrm{~K}_{2} \mathrm{~K}_{4} \mathrm{~L}_{2} \mathrm{~L}_{4} \mathrm{M}_{2} \mathrm{~N}_{1} \mathrm{~N}_{2} \mathrm{O}_{3} \mathrm{P}_{1} \mathrm{P}_{2} \mathrm{P}_{4}$ \\
\hline Dostlik & $\mathrm{A}_{2} \mathrm{~B}_{1} \mathrm{~B}_{2} \mathrm{~B}_{3} \mathrm{~B}_{6} \mathrm{C}_{1} \mathrm{D}_{3} \mathrm{D}_{6} \mathrm{E}_{4} \mathrm{~F}_{2} \mathrm{G}_{4} \mathrm{H}_{1} \mathrm{H}_{2} \mathrm{H}_{4} \mathrm{I}_{2} \mathrm{I}_{3} \mathrm{~J}_{1} \mathrm{~J}_{3} \mathrm{~K}_{1} \mathrm{~K}_{2} \mathrm{~K}_{3} \mathrm{~L}_{2} \mathrm{~L}_{4} \mathrm{M}_{2} \mathrm{~N}_{1} \mathrm{~N}_{2} \mathrm{~N}_{3} \mathrm{~N}_{5} \mathrm{~N}_{6} \mathrm{O}_{3} \mathrm{O}_{4} \mathrm{P}_{1} \mathrm{P}_{2} \mathrm{P}_{4}$ \\
\hdashline Bobur & $\mathrm{A}_{5} \mathrm{~B}_{1} \mathrm{~B}_{2} \mathrm{~B}_{3} \mathrm{C}_{1} \mathrm{C}_{5} \mathrm{D}_{3} \mathrm{D}_{6} \mathrm{E}_{1} \mathrm{~F}_{3} \mathrm{H}_{1} \mathrm{H}_{2} \mathrm{H}_{4} \mathrm{H}_{6} \mathrm{~J}_{1} \mathrm{~J}_{3} \mathrm{~J}_{4} \mathrm{~K}_{1} \mathrm{~K}_{2} \mathrm{~K}_{4} \mathrm{~L}_{2} \mathrm{~L}_{4} \mathrm{M}_{2} \mathrm{~N}_{1} \mathrm{~N}_{2} \mathrm{~N}_{5} \mathrm{O}_{4} \mathrm{P}_{1} \mathrm{P}_{2}$
\end{tabular}

Note. Locus codes are as follows: A - WMS349; B - WMC526; C - PSP3000; D - CFD76; E - WMC626; F - WMC276; G - WMC445; H - GDM33; I - WMC453; J - GPW2203; K - GPW2181; L - WMC216; M - BARC74; N - WMC104; O - WMS513; P - WMC273. The Latin letters indicate primers; while subscripts define locus allele states they mark.

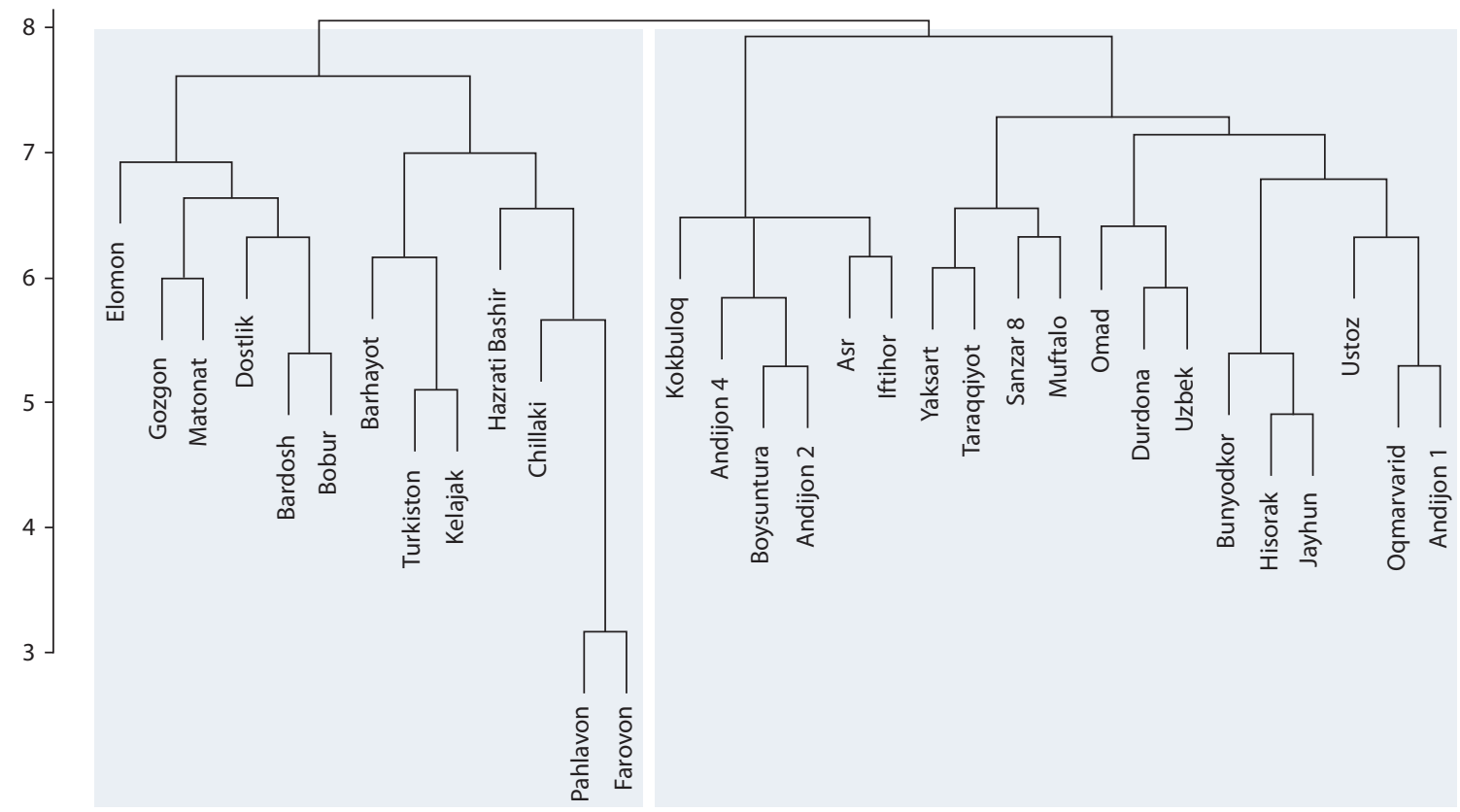

Fig. 2. Phylogenetic tree of the studied wheat varieties of Uzbekistan breeding based on 36 SSR markers.

were identified in the remaining loci (apart from CFD239) (Table 2).

Effective number of alleles is a parameter that characterizes loci in terms of allele frequencies, and it varied in the studied group of genotypes from 1.7 (BARC187) to 4.8 (WMS349), which produced an average of 2.8 alleles per locus. Average expected heterozygosity in the wheat population considered was 0.626 , as the value varied from 0 (CFD239) to 0.792 (WMS349). Amplified product sizes ranged from 93 to $552 \mathrm{bp}$. To analyze the microsatellite DNA amplification data, PIC was used, which varied from 0 (for CFD239 marker) to 0.758 (WMS349), which produced an average of 0.564 (see Table 1).

The set of microsatellite locus alleles was used to plot a dendrogram reflecting phylogenetic links between the studied soft wheat varieties. Complete link hierarchical clustering divided these varieties into two main clusters (Fig. 2), while distribution and composition of tree-like clustering mostly matched the results of k-means technique (Fig. 3).
Uzbek wheat varieties, apart from several local varieties, i.e. Pahlavon and Farovon (cultivated based on the local Marjon variety), and the traditional Boysuntura and Oqmarvarid varieties, represent genotypes obtained from various global collections and adapted to local cultivation conditions. Varieties from the first cluster, namely Elomon, Gozgon, Matonat, Dostlik, Bardosh, Barhayot, Turkiston, and Kelajak, were cultivated at Kashkadarya Research Institute of Grain Breeding and Seed Production (Uzbekistan) based on samples from CIMMYT collection (International Maize and Wheat Improvement Center), drought resistance being a prevalent breeding trait.

Varieties from the second cluster, apart from the Oqmarvarid variety, were cultivated at Research Institute of Cereal and Grain Legume Crops (Andijan, Uzbekistan) in association with Krasnodar Agricultural Research Institute named after P.P. Lukyanenko. Right subgroup of the cluster included varieties selected based on crop yield (Yaksart, Taraqqiyot, Sanzar 8, Muftalo, Omad, Durdona, Uzbek, Bunyodkor, Hisorak, Jayhun, Ustoz и Andijon 1), 


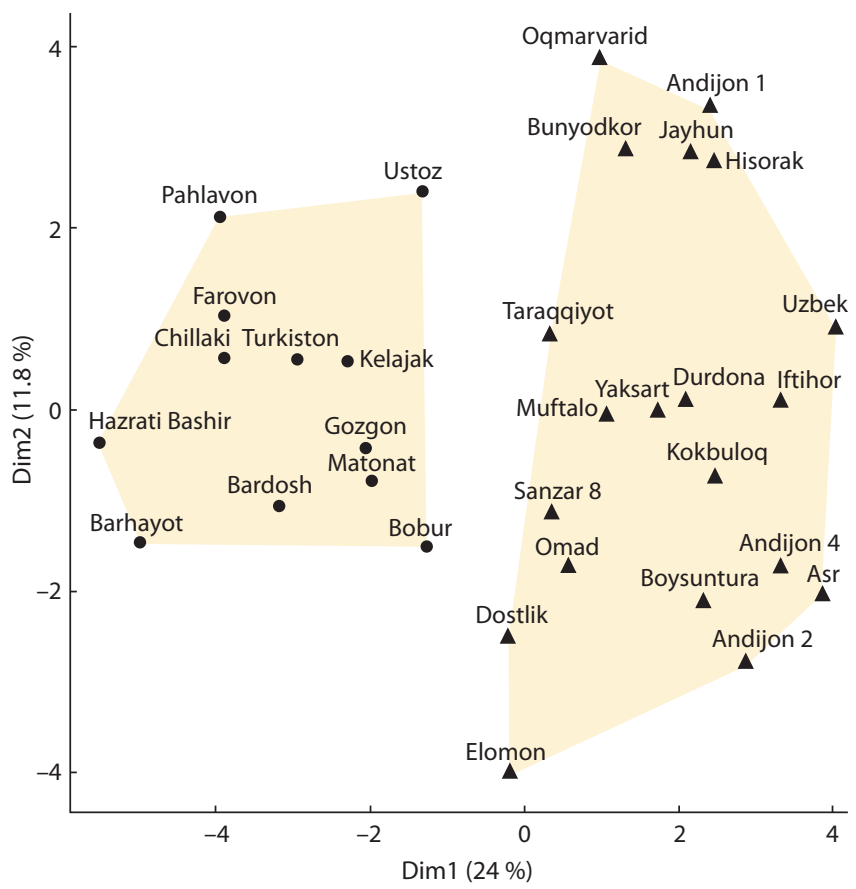

Fig. 3. k-means clustering method in studied wheat varieties of Uzbekistan breeding based on 36 SSR markers.

whereas the left one included varieties (Kokbuloq, Andijon 4, Boysuntura, Andijon 2, Asr и Iftihor) released in Gallaorol Region (Uzbekistan) and suited for dryland farming (see Fig. 2).

The PIC values obtained as a result of genotyping turn out to be sufficient for identification and certification of varieties. A fragment of molecular passport developed for promising domestically cultivated winter soft wheat varieties based on 16 most effective and informative SSR markers with $P I C \geq 0.6$ is presented in Table 2 .

The Hazrati Bashir and Andijon 1 varieties were picked as examples of genotypes at a maximum distance from each other in a multidimensional space, while the other two varieties, i.e. Bobur and Dostlik, are, on the contrary, genetically close (see Fig. 2 and 3 ).

It can be seen from Table 2 that certain sets of alleles, in particular, $\mathrm{B}_{1} \mathrm{~B}_{2} \mathrm{~B}_{3}, \mathrm{H}_{1} \mathrm{H}_{2}, \mathrm{~L}_{2} \mathrm{~L}_{4}$, and $\mathrm{N}_{1} \mathrm{~N}_{2}$ amplified by WMC526, GDM33, WMC216, and WMC104 primer pairs respectively, are detected in all four genotypes, notwithstanding the cluster they are grouped in. Since these loci are detected in most of the remaining varieties under study, they may seemingly be considered species-specific. On the other hand, there also are varieties, such as Bobur that do not include any alleles of WMC445 and WMC453 loci, which could possibly be a peculiarity of these genotypes.

Thus, we have performed screening and evaluation of genetic variety in 32 Uzbek winter soft wheat using 36 microsatellite SSR markers. These studies revealed the presence of a certain genetic variability both in terms of number of alleles per locus and genetic variety index. It was also shown that the studied varieties are clustered in accordance with their environmental, geographic, and cultivation origin.

SSR profiles made it possible to derive a genetic formula for each Uzbek wheat variety, which may be used for identification and certification of these varieties, as well as for selecting parent pairs within wheat cultivation programs.

\section{Acknowledgements}

The work was carried out within the framework of Project T.8-16 "Comparative study of DNA polymorphism of various hexaploid wheat varieties of Uzbekistan breeding using microsatellite SSR markers", supported by the Foundation for Fundamental Research Support of the Academy of Sciences of Uzbekistan.

\section{Conflict of interest}

The authors declare no conflict of interest.

\section{References}

Ayala F., Kiger J. Modern Genetics. Menlo Park, Calif.: Benjamin/ Cummings Publ. Co., 1984.

Chesnokov Yu.V., Artemyeva A.M. Evaluation of the measure of polymorphism information of genetic diversity. Selskokhozyaystvennaya Biologiya $=$ Agricultural Biology. 2015;50(5):571578. (in Russian)

Dellaporta S.L., Wood J., Hicks J.B. A plant DNA minipreparation: Version II. Plant Mol. Biol. Rep. 1983;1(4):19-21.

Devos K.M., Bryan G.J., Collins A.J., Stephenson P., Gale M.D. Application of two microsatellite sequences in wheat storage proteins as molecular markers. Theor. Appl. Genet. 1995;90:247252.

Gostimsky S.A., Kokaeva Z.G., Konovalov F.A. Studying plant genome variation using molecular markers. Russian Journal of Genetics. 2005;41(4):378-388. DOI 10.1007/s11177-005-0101-1.

Guyomarc'h H.I., Sourdille P., Charmet G., Edwards J., Bernard M. Characterisation of polymorphic microsatellite markers from Aegilops tauschii and transferability to the D-genome of bread wheat. Theor. Appl. Genet. 2002;104(6-7):1164-1172.

Khurshut E.E., Adilova A.T., Norbekov J.K., Kushanov F.N., Turaqulov Kh.S. Molecular analysis of winter wheat varieties in Uzbekistan. Uzb. Biol. J. 2017;(3):44-48.

Lowe I., Jankuloski L., Chao S., Chen X., See D., Dubcovsky J. Mapping and validation of QTL which confer partial resistance to broadly virulent post-2000 North American races of stripe rustin hexaploid wheat. Theor. Appl. Genet. 2011;123:143-157.

Nei M., Li W.H. Mathematical model for studying genetic variation in terms of restriction endonucleases. Proc. Natl. Acad. Sci. USA. 1979;76:5269-5273. DOI 10.1073/pnas.76.10.5269.

Nei M., Roychoudhury A.K. Sampling variances of heterozygosity and genetic distance. Genetics. 1974;76:379-390.

R Core Team. R: A Language and Environment for Statistical Computing. R Foundation for Statistical Computing. Vienna, Austria, 2016. Available at https://www.R-project.org.

Röder M.S., Korzun V., Wandehake K., Planschke J., Tixier M.H., Leroy P., Ganal M.W. A microsatellite map of wheat. Genetics. 1998; 149:2007-2023.

Somers D.J., Peter I., Edwards K. A high-density microsatellite consensus map for bread wheat (Triticum aestivum L.). Theor. Appl. Genet. 2004;109:1105-1114.

Song Q.J., Fickus E.W., Cregan P.B. Characteristics of trinucleotide markers in wheat. Theor. Appl. Genet. 2002;104:286-293.

Sourdille P., Gandon B., Chiquet V., Nicot N., Somers D., Murigneux A., Bernard M. Wheat génoplante SSR mapping data 
release: a new set of markers and comprehensive genetic and physical mapping data. 2004. Available at: http://wheat.pw.usda. gov/ggpages/ SSRclub/GeneticPhysical. Accessed on March 10, 2010.

Sulimova G.E. DNA markers in genetic studies: types of markers, their properties, and applications. Uspekhi Sovremennoy Biolo- gii $=$ Advances in Current Biology. 2004;124(3):260-271. (in Russian)

Zhao H.X., Liu X.M., Chen M.-S. H22, a major resistance gene to the Hessian fly (Mayetiola destructor), is mapped to the distal region of wheat chromosome 1DS. Theor. Appl. Genet. 2006;113:1491-1496 